\title{
展望・解説
}

\section{燃焼火炎の可視 化*}

佐 藤 誠四郎**

\section{Laser Aided Visualization of Combustion Flame}

\section{Seishiro SATO}

\section{1. まえがき}

最近の燃焼の可視化の特徵は, ある断面に打け る物理量を瞬間の空間分布として 2 次元平面上に 表示する例が多いことである。これは近年のレー ザや撮像管などの電子機器およびデータ処理技術 等の進歩を背景としており，とくにレーザ分光法 では主に 1 点の計測だったものが, 瞬時の 2 次元 イメージ計測が可能になり燃焼の可視化手法とし て有力なツールとなっている1)。

燃焼研究にとって可視化の重要性は論をまたな い。例えば対象とする現象等の詳細な計測や解析 を行う前に，あるいはこれと並行してなんらかの 方法で対象場を可視化し，全体的なイメージを把 握することによって理解や指針等を得るのが一般 的な研究手法と思われる。内外の燃焼シンポジウ ムなどの報告では, このための可視化の手法とし て従来からシュリーレン法が最も多く用いられて いる。最近ではシート状にしたレーザビームを用 いた断面像や前述の分光画像, さらにはいくつか の手法を組み合わせた同時複合計測法 ${ }^{2)}$ が用いら れている。これら断面像や分光画像の多くは, デ 一タの数学的な変換等が不要であり，そのままで 理解しやすく現象を直感的に把握できること, ま た 1 点の計測法を強力に補間する方法として有力 視されている11。

以上のように燃焼の可視化の重点は, 現象を 2 次元的に把握することにあるが，最終的には非定 常現象中での諸量の瞬間状態3)などの 3 次元的な 現象の理解が必要なことはいうまでもない。燃焼

*原稿受付 1990 年 4 月 19 日

**正会員 船舶技術研究所
の画像計測を中心とした可視化や研究の動向につ いては，すでに解説，展望がなされているので),51 本稿では, 瞬時の 3 次元空間分布の測定が可能な レーザ干渉法とコンピュータ断層撮影法 (CT) に上る火炎の温度分布の可視化を中心に，原理， 適用例およびレーザ分光法によるイメージ計測例 など，レーザを用いた燃焼計測法の概要について 述べる。

\section{2. 燃焼のレーザ応用計測}

レーザ応用計測の特徵は, 非接触で対象場を乱 さないこと, 時間, 空間分解能が優れていること, 従来の計測法では得られない新しい情報が得られ ることなどである。

対象とする燃焼場にレーザを照射すると，レー ザは図 1 に示すように透過, 屈折, 散乱掞よびシ 一ド粒子等によって反射される。これらのレーザ の情報は，対象とする然焼状態を反映しているの でここれから診断が可能である。

レーザの透過情報を基にした計測法としては, レーザ光の減衰などの強度変化を検出するもの, 燃燒場によるレーザの速度变化を位相情報として 検出する干渉法があり, マッハッェンダー法, ホ

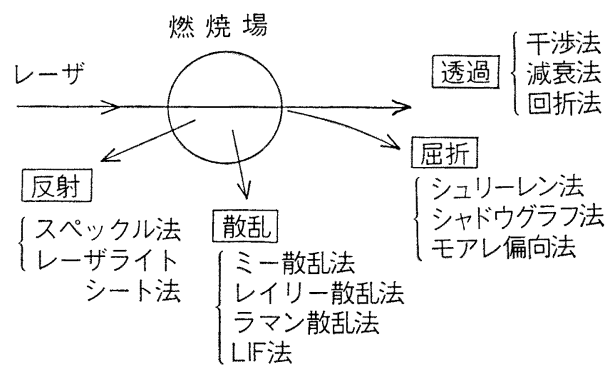

図 1 レーザ応用計測 
ログラフィ法などが用いられる。レー ザの屈折を基にした方法には, シュリ ーレン法, シャドウグラフ法, モアレ 偏向法があり，ともにレーザの進行方 向之直角方向の密度勾配の情報が得ら れる。これら透過法, 屈折法の特徵は, レーザ進行方向の積分值が得られるの で，一般に回転対称など分布形状がわ かっている場合の他は, 局所值を求め るには CTとの組合せが必要となるこ とである。

散乱情報を基にした方法には, 照射 したレーザと波長シフトの生じないミ 一散乱, レイリ一散乱波長シフトの生 ずるラマン散乱などがあり，一般に局 所值が得られ成分濃度, 温度等が計測 される。またレーザによる蛍光を利用

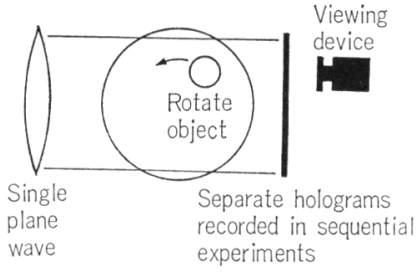

1) 回転, スキャンニング方式

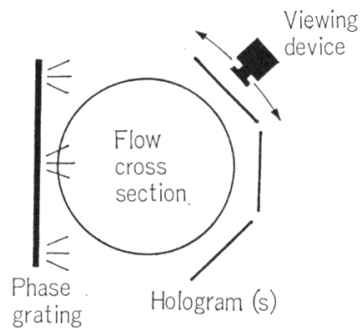

3）位相格子照明方式

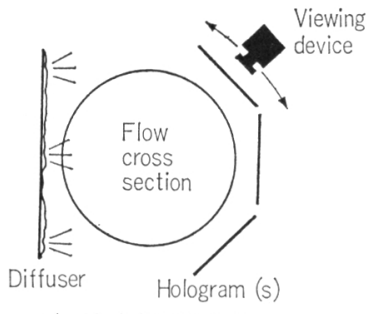

2）拡散光照明方式

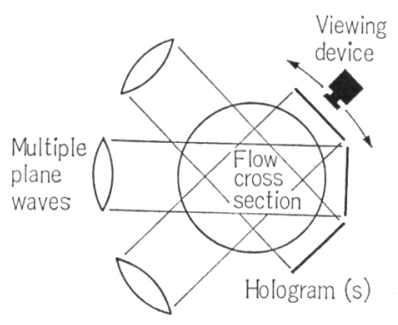

4) マルチプルビーム方式

図3CT データの収集,

したレーザ誘起蛍光法があり，信号強度が強いの で平面光束を用いるとラジカル等の 2 次元的な検 出が可能である。反射情報を用いるものとして, レーザライトシート法による火炎面形状や渦構造 の観察などが行わ机ている。

\section{3 次元温度分布計測}

レーザ干渉法を用いた火炎温度の測定原理を図 $2^{6)}$ に示す。前述のように, 干渉法では対象火炎 の光路方向に沿った屈折率の積分量が得られるの で, 局所の值を求めるには, 通常温度場が 2 次元 分布之か, 回転対称 (軸対称) 分布の場合に限定 される。しかしCTを用いることによって, 分布 形状が任意の場合でも局所的な值のみならず広い 範囲の空間分布の測定が可能となる。また気体の 屈折率は密度の関数であり, 密度はガス組成, 温 度, 圧力によって変化するため, 温度を求めるに はガス組成と压力が必要となる。このうちガス組 成の影響は, 炭化水素火炎の場合は小さく, ガス

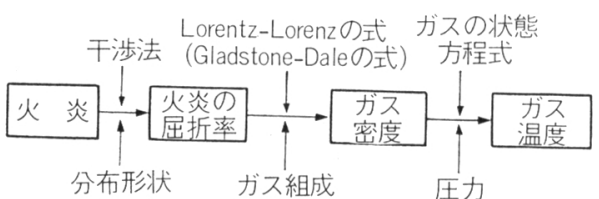

図 2 温度測定原理

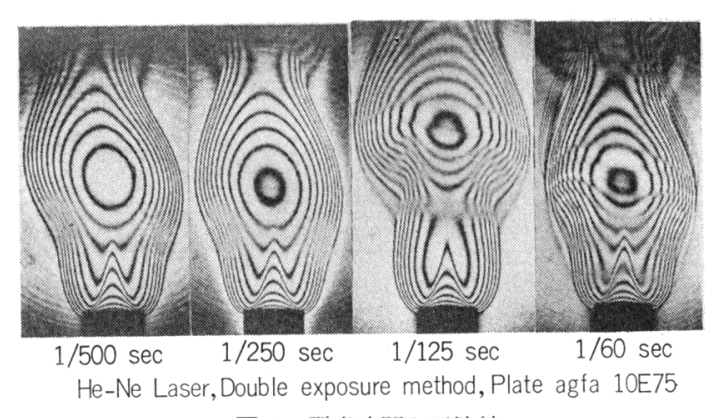

図 4 露光時間と干渉縞

組成を燃焼がスの代わり空気として求めても誤差 が最大 $4 \sim 5 \%$ 以内であることが明かにされてい る?。

\section{1 多方向干渉光学系}

CT 適用するには， $180^{\circ}$ に方たる円周方向から の投影データが必要である。本節では, 火炎以外 への適用の場合を含めて多方向干渉光学系の現状 を述べる。

多方向からの干渉データを得る方法として図 3 に示す X線CT スキャナと同様に回転, スキャン ニングによる方式, 拡散光照明を用いる方式, マ ルチブルビーム方式などが提案されている ${ }^{8)}$ 。し かし多方向干渉法を火炎に適用する際, 干渉デー タの取得時間の問題がある。図 4 はブンゼンバー ナ火炎の干渉写真を示す。図から CT 計算に用い 
る干渉縞の次数を一義的に测るには, 露光時間を 少なくとも $1 / 250$ 秒以内にする必要があることが わかる。

1）回転スキャンニング方式

光学系または物体を回転する方式である。干涉 法では火炎が完全に定常であっても，回転による 光学系のずれなどを光の波長のほぼ1/10以内にし なければならないため安定性などの点で難しく, 一つの干渉計を固定しておいて物体を逐次回転す る方式が採用されている。Hertz ${ }^{9)}$ はマッハッェ ンダー干渉計を用い，対象物体を撮影ごとに回転 させ多方向の干渉像を得ている。

レーザビームを回転する方式として, Snyder ら ${ }^{10)}$ は図 5 に示すよう反射ミラーを固定し, 二つ の同期回転ミラー（図の記号M1，M2）を用いて ビームを回転させ，多方向の干渉像を得る方法を 提案している。各方向の像の分離, ビームの安定 化を確実に行えば，時間分解能も500１000方向 ノ秒と高く有望な方法と思わ机る。

2）昖散光照明方式

対象物体の照明光をスリガラスなどに通して拡

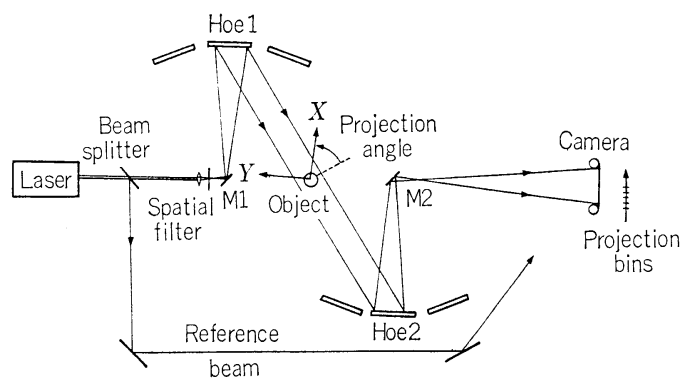

图 5 山転方式光学計 ${ }^{100}$

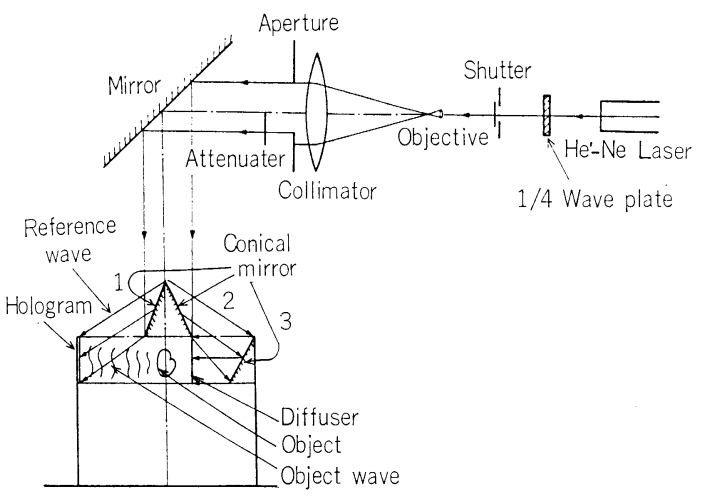

図 6 拡散照明光学計 ${ }^{11}$
散光として用いる方法である。Murata ら ${ }^{11)}$ は加 熱空気の流机場の測定に図 6 に示寸本格的な多方 向干渉光学系を提案している。図 6 の光学計で は干渉像が得られる円周方向の角度範囲は150 $160^{\circ}$ である。

拡散光照明方式では，円周方向に連続した多方 向の干渉像が得られる利点がある。しかしレーザ 光量の損失が大きく高出力のレーザが必要なこと, 干渉縞が特定の位置に局在するため, 干渉像の再 生の際フリンジと物体を同時にピントを合わせる 必要からカメラの絞りを小さくしなければならず, これに伴いスペックルノイズが増し干渉縞の解像 が悪くなるなどの問題がある。

3）位相格子照明方式

Sweeney ら ${ }^{12)}$ は拡散光照明に伴うスペックル ノイズを低減するため, 1 本のビームから幾つか の方向に伝播する波面が得られる位相格子を用い ている。一つの位相格子につき約 $20^{\circ}$ の範囲で 8 方向の干渉像が得られるとしている。ビーム強度 の利用効辩の向上等の問題があると思われる。

4) マルチプルビーム方式

平行光などの指向性のビームを用い, 全部の干 渉像の撮影を瞬時に得る方法としてマルチプルビ 一ム方式がある。図 7 は 4 方向の干渉像が得られ る配置例である13)。図でわかるように, この方式 では光学部品が多数必要なことが難点である。ホ ログラフィ法では通常, 参照光, 物体光を用いる ので, マルチプルビーム方式では撮影方向数のほ

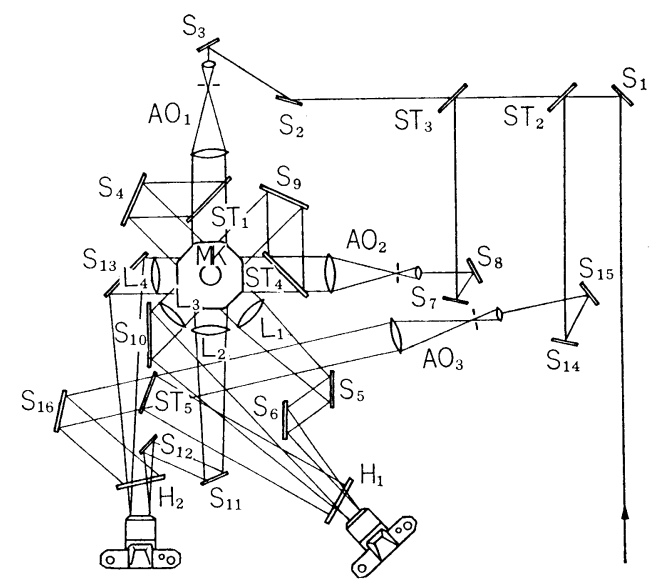

図 74 方向干渉光学計 ${ }^{13)}$ 


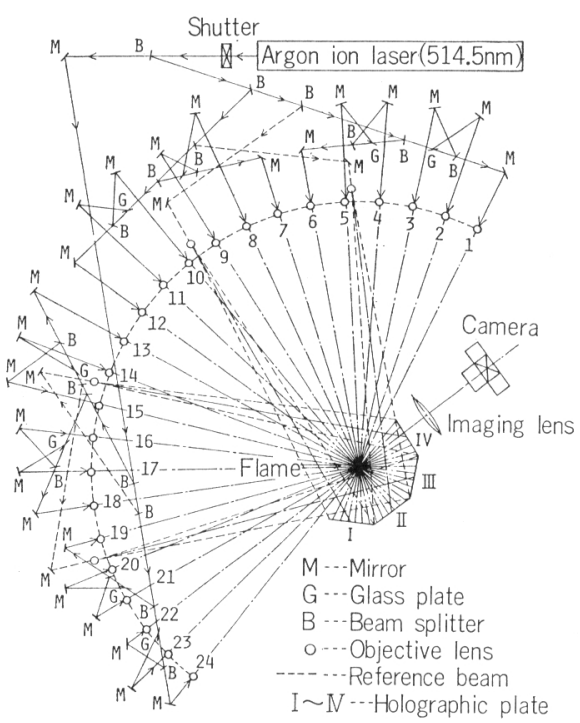

図 8 多方向ホログラフィ干渉計 ${ }^{14)}$

注 2 倍のビームが必要となり所要部品も多くなる。 図 8 は円周24万向からの干渉像が一度に得られる もので, 光学部品を減らすため, 参照光は物体光 6 個每にし，平行光を用いる代わりレンズからの 発散光をそのまま用いている。多方向の干涉像は, 約 6 万向をまとめて 1 枚の乾板に多重記録する。 本光学計では, 干渉像を撮影できる角度範囲は $168^{\circ}$ ，視野は縦，横とも $80 \mathrm{~mm}$ が得られている到。

以上のように多方向干渉光学系では, レーザ光 量, 光学部品の制約などから干渉像が得られる角 度範囲, 撮影方向数, 視野の大きさが限られるな ぞの問題がある。

\section{2 温度分布}

干渉法による温度測定では, 李ず火炎の屈折率 を求める必要がある。干渉写真は, 対象物体の屈 折率分布の投影を表すので，CTの再構成計算に より屈折率が求められる。再構成計算には種々の 方法があり, 通常重畳積分法が用いられている。

火炎温度 $T$ は, 再構成計算に上り求めた屈折率 から Gladstone-Dale の式执よび気体の状態方 程式を用いて次式から求められる7)。

$$
\begin{aligned}
& \quad \frac{1}{T}=\frac{P_{0} \cdot K_{0} \cdot G}{P \cdot K \cdot G_{0}}\left\{\frac{1}{T_{0}}-\frac{R(x, y)}{\rho_{0} \cdot K_{0} \cdot T_{0}}\right\} \\
& \text { ただし, } \\
& \quad R(x, y)=N_{0}-N(x, y) \\
& \text { ここに, } P: \text { 圧力, } G: \text { ガス定数, } K:
\end{aligned}
$$

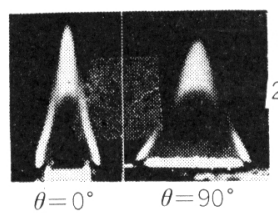

(a) 直接写真

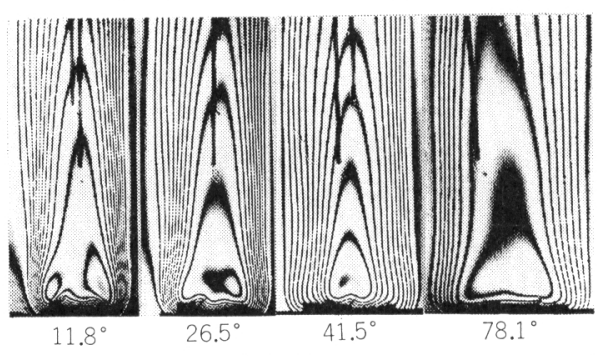

Projection angle

図10 アルコール芯火炎 ${ }^{14)}$

(b) 芯の構造
Gladstone-Dale 定数, $N$ : 屈折率, $\rho$ : 密度, $x$, $y$ : 平面座標, 添字 0 : 基準状態 (通常大気室温) を表す。

\section{3 適用例}

レーザ干渉，CT 法の適用例として Hertz ${ }^{9)}$ は マッハッェンダー干渉計を用い，メタン拡散火炎 を回転して得た 8 万向の干渉写真を用いて，図 9 に示吉水平断面の温度プロフィールを求めている。 図10は24万向干渉光学計を用いてアルコール芯火 炎の干渉写真の一例であり，図11，図12はこれか ら求めた水平断面の温度プロフィール执よび垂直 断面の等温線を表示したものである。また温度の 空間分布の表示方法として, 火炎の温度分布形状 をソリッドモデルのシェーディング表示した例が ある。図1315)にはこ扎を示し，図11などと同様に して求めたアルコール芯火炎の温度分布の立体形 状であり，垂直面と水平面（同㘠ａ）拈よび傾斜

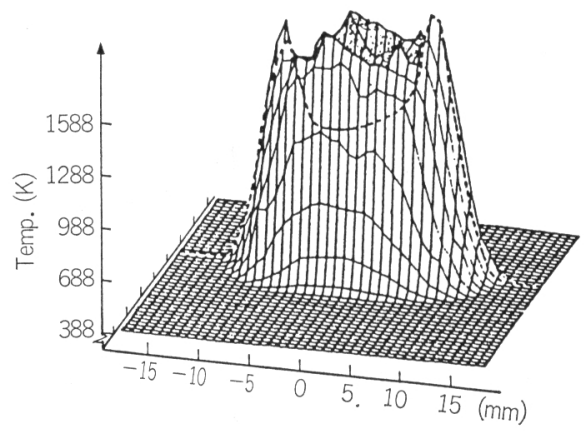

図 9 ×タン拡散火炎の温度分布 (水平断面) ${ }^{92}$

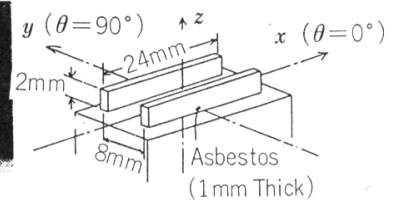




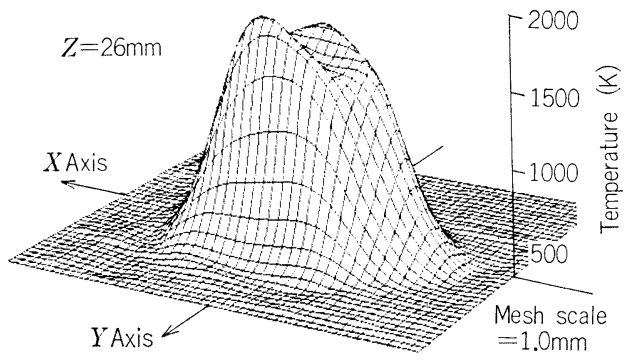

図11 アルュール芯火炎の温度分布(水平断面)

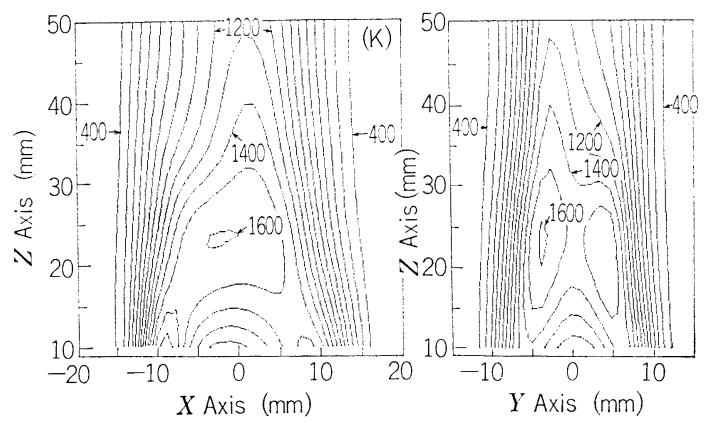

図12 アルコール芯火炎の等温線分布(垂直断面)
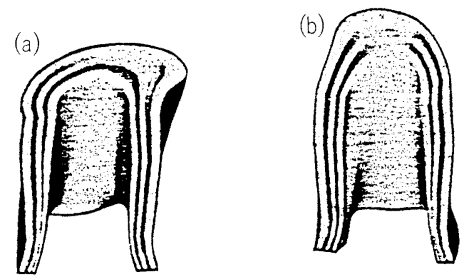

(外側温度400K, 内側温度1150K, 温度間隔150K)

図13 温度分布のソリッドモデルによる表示 ${ }^{15}$

面（同図 b ）で切断した等温面形状を示す。

図14 ${ }^{16)}$ はは同じ24方向干涉計を用いて測定した 層流予混合バーナの温度プロフィールを示す。図 15は同じバーナの乱流条件の温度プロフィールで あり，干渉写真の撮影には光源にルビーレーザを 用いる 8 方向マルチパス干涉計を用いている17)。

図16は図15と同じ干渉データを用い，軸対称分布 の仮定からアーベル変換で求めた温度分布の例で あり，各方向で温度レベルが異なっている。この 結果は, レーザ干渉法による温度測定では, 流れ で規制された円錐状火炎の場合でも，従来用いら れている軸対称の仮定では, 定性的な傾向は求め られるが，定量測定にはCT が必要であることを 示すものである。

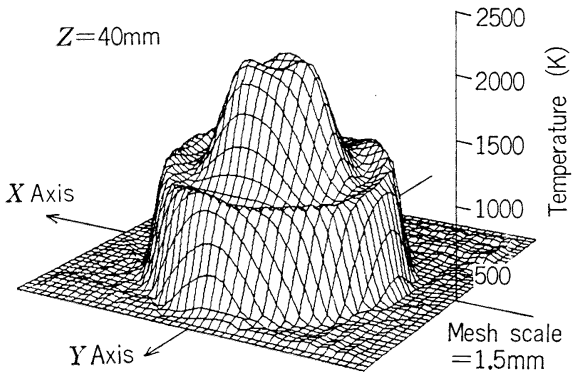

図14 層流予混合火炎の温度分布(水平断面 $)^{16)}$

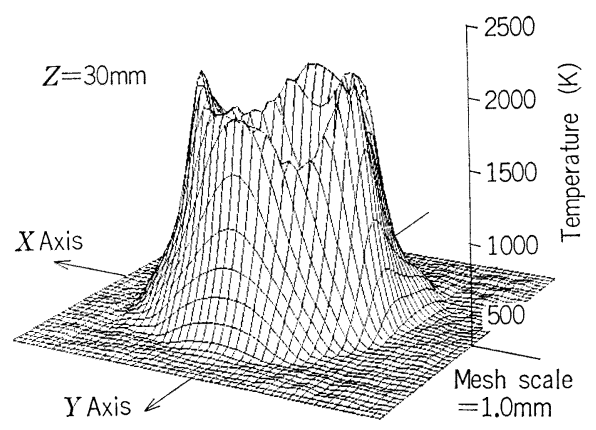

図15 乱流予混合火炎の温度分布(水平断面) ${ }^{17)}$

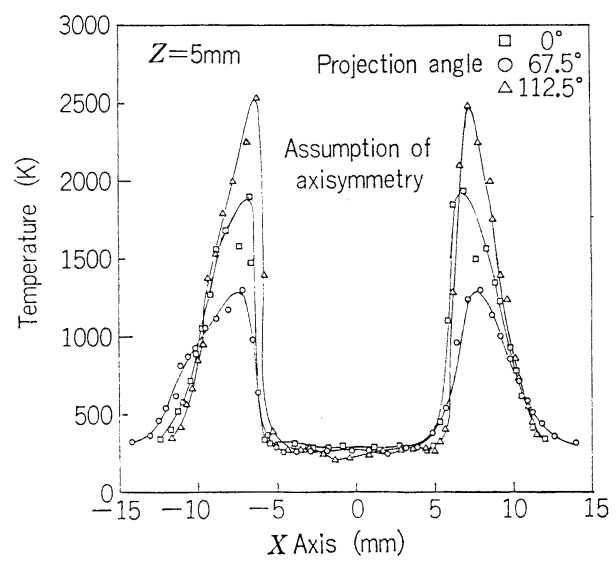

図16 軸対称の仮定による温度分布 ${ }^{17)}$

レーザ干渉，CT 法では，多方向の干渉写真を 用いるため膨大なデータ処理を必要とすること, 干渉縞の画像処理では, フリンジパターンの頂上 か谷かなどの判断を要するため，データ処理の自 動化が困難なことなどがある。また気体の屈折率 は高温になると変化が小さくなり，精度向上には 干渉法の検出感度を高める必要がある。このため, フーリエ変換干渉法 ${ }^{18)}$ をCT に適用し, データ処 


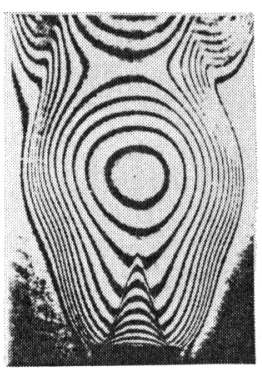

ホログラフィ法

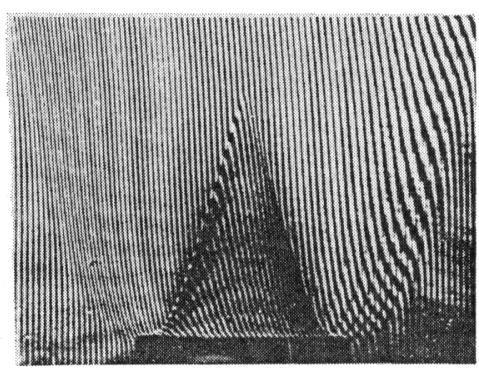

フーリエ変換法
図17 従来法, フーリ工変換法干渉写真 ${ }^{18)}$

理の自動化と測定精度の向上が図られている。フ ーリエ変換干渉法 ${ }^{191}$ は，図17 亿示すように従来の 干渉縞に干渉光線を傾けて得られる等間隔の縞を 加光，空間的に変調した干渉縞をもとに位相を抽 出する方法で，照明むらなどによる不要な信号を 精度良く分離，除去できる。フーリェ変換法では， 1 フリンジ以下の精度が容易に得られること。コ ンピュータによる処理に適していること。干渉縞 次数の勾配 (增減) が自動的に判別できることな ぞである。

\section{2 次元計測}

\section{1 レーザライトシート法}

瞬間の火炎面形状を可視化するため，ある断面 をシート状のレーザ光で照射し火炎中に混入させ た微粒子からの散乱光の強度変化によって, 燃焼 領域と末燃領域などを識別する方法でレーザトモ グラフィとも呼ばれている。

図18に測定装置 ${ }^{20)}$ 示し, 図19は水素拡散火炎 の僢間像である ${ }^{21)}$ 図19では, YAGパルスレーザ を用い火炎の発光を除くため，干渉フィルターお よびレーザと同期したゲーティングを行っている。 本方法を用いて，火炎面形状のフラクタル解析や， 火炎の渦構造と混合の関 連などが調べられている。

\section{2 平面 LIF}

レーザ誘起蛍光法 (LI F）は，火炎の安定成分 のみならず $\mathrm{OH}, \mathrm{CH}$, NO など然燒反応の進行 を支配するラジカル（活 性基) 濃度の瞬時の空間

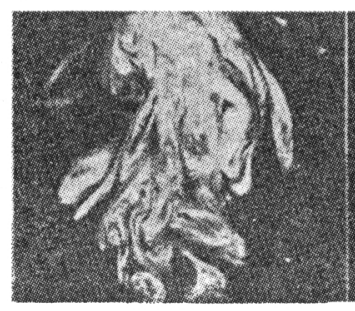

$140 \mathrm{~mm}$

分布を可視化できる。この方法は測定成分に応じ た固有の波長のレーザ光を照射し，対象成分のエ ネルギ準位を励起させ，基底状態に遷移する際の 蛍光強度から濃度などを求めるものである。蛍光 法では条件によって，他の分子による衝突や放射 等の影響があり，これらを考慮した測定が検討さ れている22!。

平面 LIF ( Planar Laser Induced Fluorescence) はレーザシート光による蛍光を 2 次元的 に検出する方法であり，図20はとの装置例 ${ }^{23)}$ であ る。図21 は図20の装置を用いたプロパン拡散火 炎の $\mathrm{OH}$ の水平断面の瞬間像之平均像である。こ の上うな 2 次元計測法の拡張として，レーザシー 卜照射面の高速スキャンニングによる 3 次元イメ ージ計測が試みられている1

\section{3 同時複合計測}

乱流火炎では，温度，密度，濃度，流速などす べての量が変動して预り，単独の量の測定によっ て現象のすべてを理解することはむずかしく24)， また 2 種類の量の相関が火炎構造などの理解に必 要とされている4)。このためレーザ誘起蛍光法,

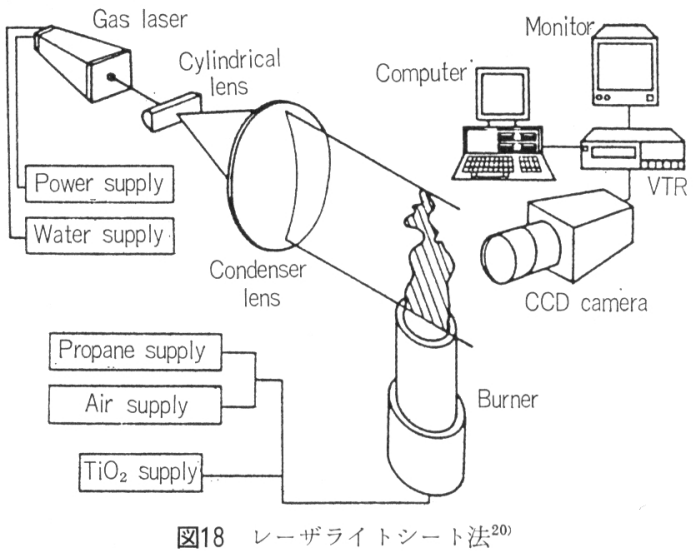

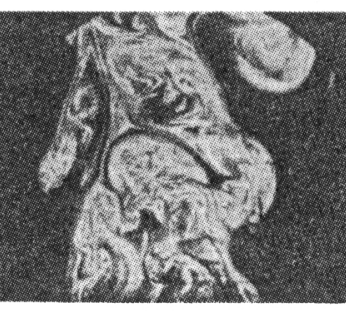

$170 \mathrm{~mm}$ ノズル出口からの距離

図19 水素拡散火炎の瞬間像 ${ }^{21}$

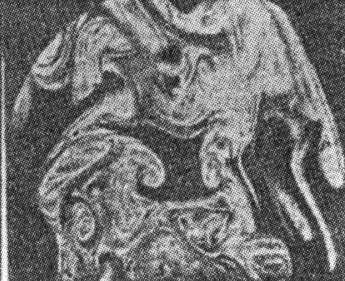

$200 \mathrm{~mm}$ 


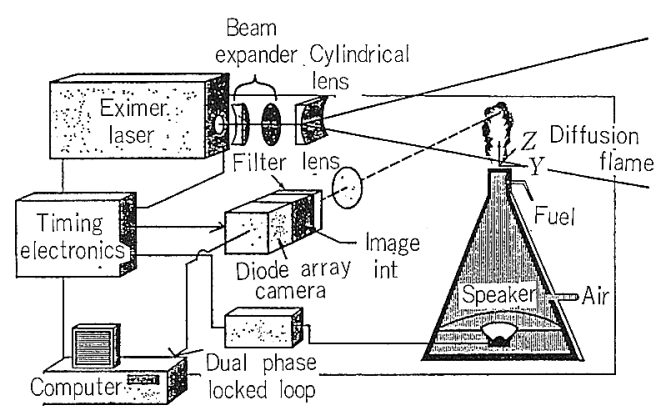

図20 平而 LIF 実験装置 ${ }^{23}$

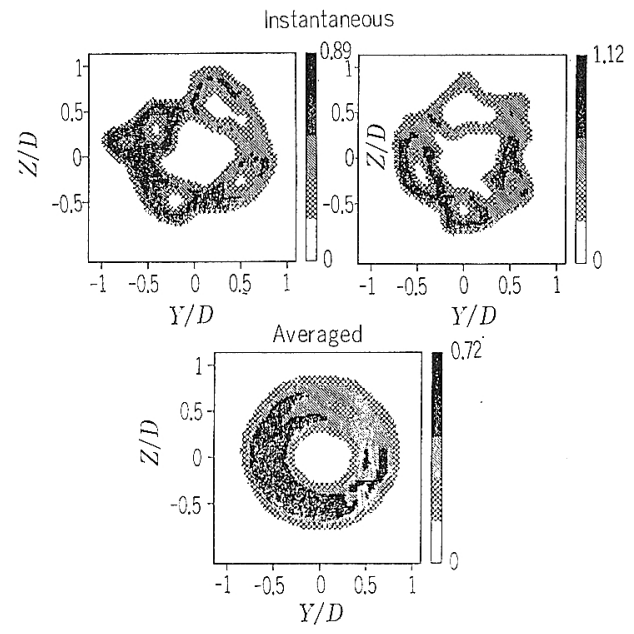

図21 プロパン拡散火炎の $\mathrm{OH}$ 像 ${ }^{233}$

ラマン散乱法ミミ一散乱法などを組み合わせて， 各種成分濃度や温度の同時測定が行われている。 図2225) は, 乱流拡散火炎の $\mathrm{CH}$ の蛍光像と $\mathrm{CH}_{4}$ の ラマン散乱像を示し，2波長レーザを用いてこれ らの像を同時に計測できるシステムを用いている。 二つの像からフレームフロントの位置が決定でき るとしている。また図2326) の上図は噴流拡散火炎 の平面 LIF による OH 像，下図はシード粒子に よるミ一散乱像を表し，これらの像の組合せによ って火炎構造の情報が得られる。

\section{5.あとがき}

レーザ干渉，CT 法による火炎温度測定につい て，筆者の行っている結果を中心に述べた。現状 では，本方法はデータ処理に手間と時間がかかり， 手軽に使える手法となっていない。これは，ホ口

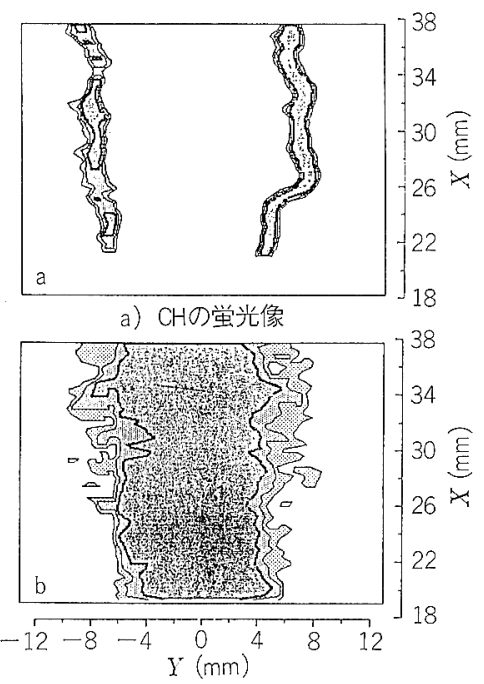

b) $\mathrm{CH}_{4}$ のラマン散乱像

図22 乱流挫散火炎の $\mathrm{CH}-\mathrm{CH}_{4}$ イメージ25)

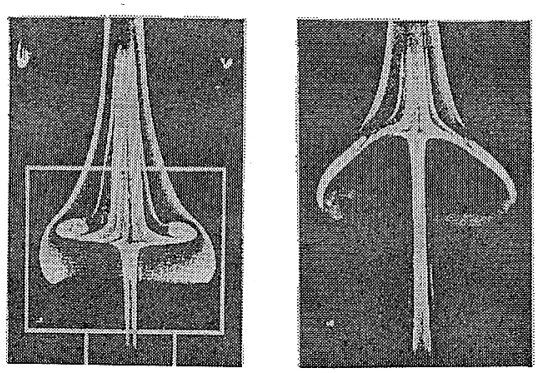

$\mathrm{OH}$ 蛍光像

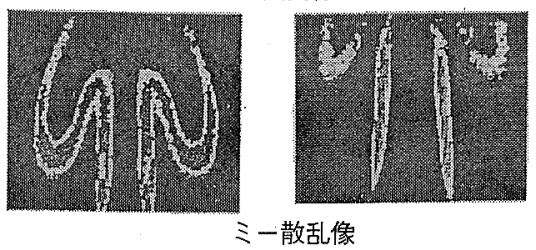

図23噴流拡散火炎の分光像 ${ }^{26)}$

グラムの記録に従来写真の銀塩方式を用いている こと, 干渉縞の画像処理やデータの数学的变換が 必要なことなどによっている。

今後は電子写真方式を用いること，画像処理の 自動化やインテリジェント化をはかること, 計算 処理の高速化などにより，瞬時の空間的温度分布 のオンライン測定の注か，高速度カメラを用いれ ば空間分布の時系列測定が可能であり，分光法に よる 2 次元イメージ計測の相補的計測法としても 発展することが期待される。 


\section{参考文献}

1) Hanson, R. K. : Combustion Diagnostics : Planar Imaging Techniques, 21st Symp. (International) on Combustion, (1986), 1677.

2）塩路：燃焼の計測および診断技術, 機械学会関西支部, 172 回講習会教材, (1990), 1 .

3) 水谷：燃焼研究と燃焼技術の動向之問題，機械学会論文集 B編，54-502，(昭63-6), 1215.

4) 水谷：燃焼の画像計測, 流れの可視化, 8-28, (1988-1), 24.

5) 竹野: 燃焼学の新しい研究方法の動向, 航空宇宙学会誌, 37-421, (1989), 91.

6）佐藤：レーザ干渉法による燃焼計测, 光技術コンタクト, $26-2,(1988), 132$.

7）佐藤，ほか 2 ：機械学会論文集B編，ホログラフィ干渉法 に上る火炎温度分布測定，53-490，(昭62-6), 1852.

8) Vest C. M. : Optical Metrology and Computer Tomography for Measurement of Temperature and Density, NATO ASI Ser E, 131, (1987), 343.

9) Hertz. H. M. : Experimental Determination of 2-D Flame Temperature Fields by Interferometric Tomography, Optics Communications, 54-3, (1985), 731.

10) Snyder. R., Hesselink L. : High speed optical tomography for flow visualization, Appl. Opt., 24-23, (1985), 4046.

11) Murata K. et al: Holographic interferometry with a wide fiels of view and its applications to reconstruction of refractive index fields, Optik, 53-4, (1979), 285.

12) Sweeney D. W. : Experimental Capabilities of Holographic Interferometry, Goulard R. Edi., Combustion Mesurements, Hemisphere Publ. Corp. (1976), 262.

13) Lübbe D., Mayinger F.: Die optisch holographishe
Tomographie-ein Meß fahren zur Erfassung instationärer dreidimensionaler Mischvorgänge, Ver. Dtsch. Ing., 545, (1984),1271.

14）佐藤, 熊倉：レーザ干渉法とCT 法による火炎温度分布測 定，機械学会論文集 B編, 55-511, (1989-3)，841.

15) Doi, J., Sato, S. : Three-Dimensional Reconstruction of Flame Structures using Multiple Interferograms, Proc. Int'l Conf. on Optical Methods in Flow and Particle Diagnostics, Laser Institute of America, (1988),131.

16）機械学会編：燃焼のレーザ計測とモデリング (1987), 363. 丸善.

17）佐藤ほか 2 ：第26回燃焼シンポジウム前刷集（昭63-11）. 13.

18）佐藤ほか 2 : 第27回燃焼シンポジゥム前刷集,（平元-12）, 374.

19）武田：サブフリンジ干渉計基礎論, 光学, 13-1, (1984), 55.

20）安藤, 吉用：第27回燃焼シンポジウム前刷集, (平元-12), 389.

21）森口ほか３：機械学会関西支部第65期講演会概要集，904-2 (平2-3), 39 .

22）出口ほか $2:$ レーザ誘起蛍光法を開いた $\mathrm{OH}$ の温度・濃度 計測，機械学会論文集B編，55-517, (1989-9), 2830.

23) Gutmark, E. : Azimuthal Structure of an Annular Diffusion Flame, Combust. Flame, 75, (1989), 229.

24）香月：乱流火炎の計測，機械学会論文集 B 編，55-510, (1989-2), 261.

25) Namazian, M. et al: Two-wavelength single laser $\mathrm{CH}$ and $\mathrm{CH}_{4}$ imaging in a lifted turbulent diffusion flame, Appl. Opt., 27-17, (1988),3597.

26) Vandsburger, U. et al: Visualization Methods for the Study of Unsteady Non-Premixed Jet Flame Structure, Combustion Sci. and Tech. 59, (1988), 455. 